\title{
THE EXPLANATORY UTILIZATION OF VERSES OF REASON AND SCIENCE IN THE THOUGHT OF IMAM KADHUM (PBUH)
}

\author{
Asst. Dr. Mayas Dhiyaa Baqir \\ College of Education ibn Rushd. \\ Department of Holy Quran Sciences and Islamic Education
}

DOI: $10.37648 /$ ijrssh.v10i01.031

Received:20 ${ }^{\text {th }}$ October 2019; Accepted:30th November, 2019; Published:16 $6^{\text {th }}$ December, 2019

\begin{abstract}
The greatness of the people of the house (and distinguishes them from) in their entire human self is the rest of the people in the reflection, which is characterized by the good and the absolute perfection, and the sincere direction, the knowledge of the Almighty in their ideal life and their perfect life. (He explained and interpreted the meanings of the Qur'an in particular with regard to reason and science, affirming them as the way to know and build man, build his civilized, righteous culture, and justice. It has linked the Qur'anic verses that speak of reason with verses that speak of science, showing the purposes he wanted in these verses and how to use them in our lives and building our future.
\end{abstract}

\section{INTRODUCTION}

Praise be to Allah. Praise be to Allah.

The Ahl al-Bayt (the prophet's household) (peace be upon them) is distinguished from the rest of the people in their full knowledge of God Almighty, and the pure orientation of Him, which is characterized by good and absolute perfection, and the reflection of this knowledge behavior and work in their ideal eternal life.

The biography of Imam al-Kadhim (p) struggle, as a beacon and an example of moral and educational values in the life of the nation, as this giving march was characterized by solidity and steadfastness, and a genuine recognition of the biography of the Prophet Muhammad (peace be upon him) with behavior, performance and giving, it is no wonder to see in his biography (P) Asceticism and sacrifice, and making money and soul in order to reach the pleasure of God Almighty, and work to save humanity and put it on the path of guidance.
This is evident in his intellectual tender, which emphasized the mind and its importance and its relationship with science and knowledge, and the use of the verses of reason and science in his thought (PBUH). We have to invest and invest in building the Islamic civilization and the education of the believer, so I have highlighted this aspect of the tender of the Imam intellectual; because it emphasized the mind and its importance significantly through his recommendations and words.

This is an objective study that includes two topics:

First: Definition of the mind and indicate its importance and its relationship to science.

The second topic: dealing with the use of verses of reason and science in the thought of Imam Kadhum (PBUH). 


\section{SECTION ONE}

\section{DEFINITION OF THE MIND AND INDICATE ITS IMPORTANCE AND ITS RELATIONSHIP TO SCIENCE}

\section{Definition of mind}

Ibn al-Faris said: - The mind: is the custodian of the reprehensible words and deeds ${ }^{1}$.

Hebron said: - Mind: - the opposite of ignorance, it is said: mind reason mind, if he knew what he did not know before, or exploded what he does, and collected minds ${ }^{2}$.

And mind: stone and forbidden, and a reasonable man and minds ${ }^{3}$.

And the mind of the thing: - Understand and manage.

And so and so mind: - knew the error that it was.

\section{Mind Importance}

Thinking and reasoning are the mainstay of Islam. Sanity, and learning, are emphasized in their guidance more than anything else. Islam believes that reason is the basis of man, a criterion for its value and the degree of perfection. It called for the use of thought and the use of reason that believes in reasoning and denies dependency and blind tradition, says Almighty in his glorious book "And it is not (proper) for the believers to go out to fight (Jihâd) all together. Of every troop of them, a party only should go forth, that they (who are left behind) may get instructions in (Islâmic) religion, and that they may warn their people when they return to them, so that they may beware (of evil)"(AtTawba/122). Moreover, Allah the Almighty has said "When it is said to them: "Follow what Allah has sent down." They say: "Nay! We shall follow what we found our fathers following." (Would they do that!) even though their fathers did not understand anything nor were they guided?" (Al-Baqara /170). Allah also says "And if you obey most of those on the earth, they will mislead you far away from Allah's Path. They follow nothing but conjectures, and they do nothing but lie." (Al-An'aam116). Additionally, Allah says "See you not that Allah has subjected to you (mankind) all that is on the earth, and the ships that sail through the sea by His Command? He withholds the heaven from falling on the earth except by His Leave. Verily, Allah is, for mankind, Full of Kindness, Most Merciful." (AlHajj/ 65). God Almighty ordered the believer to think under his hand in the earth, and above the orbits to know but he, because they ridiculed him and humiliated to his will, so called the Koran to look at the universe and creatures, as He says "Travel in the land and see how (Allah) originated the creation, and then Allah will bring forth the creation of the Hereafter (i.e. resurrection after death). Verily, Allah is Able to do all things." (Al-Ankaboot / 20). Also, Allah has said "Do they not look in the dominion of the heavens and the earth and all things that Allah has created; and that it may be that the end of their lives is near. In what message after this will they then believe?" (Al-A'raaf/ 185). These verses and others clearly call for the use of reason and the consideration of cosmic creatures, and also called the Koran mind to look carefully at the wisdom behind the prayer as saying "Observing Saum (fasts)] for a fixed number of days, but if any of you is ill or on a journey, the same number (should be made up) from other days. And as for those who can fast with difficulty, (e.g. an old man), they have (a choice either to fast or) to feed a Miskîn (poor person) (for every day). But whoever does good of his own accord, it is better for him. And that you fast is better for you if only you know." (Al-Baqara / 184).

Islam as the last heavenly religion came to the good of man, appreciates the mental energy and manages to use pores in the goodness of people until the Day of Resurrection. Mind is not used, as the previous verses have shown, and these are revolutionary data of intellectual freedom in Islam, the war waged against tradition and the rigidity of thought, And the surrender of mental myths or the opinions of others without consciousness and scrutiny, and the goal of Islam is the formation of the reasoning or proof of the human, it is in the view of Islam to create a free thought to create the reasoning man who does not accept the idea without research and do not believe in a doctrine You have no proof, so that this conscious mind is a guarantee of intellectual freedom and a capital of man from being abandoned, motivated by imitation or intolerance, or based on superstition, and in fact this is part of the battle of Islam to liberate the internal content of man., Well free Human consciousness from the 
bondage of tradition, and this or that he became a free man in his thinking and free in his will ${ }^{4}$.

This is confirmed by the narrations of the Prophet (peace be upon him) and his household (p), said the Messenger of Allah (peace be upon him and his family) (not one of you bright says that I am with the people that the best people are well done and if they misunderstood), the imam said Ali (p) (if God wants a good slave give him a strong mind and a righteous act) 5 .

The Imam Ali (AS) recommend his son Hassan (AS) and says: (... O sons of poverty is more than ignorance, and no more than the lack of reason ... Nor worship such as thinking of God Almighty, O son of the mind Khalil one. It is necessary for the sane to look at it ...), ${ }^{6}$ and saying (p) (not as rich as the mind and poverty as ignorance and inheritance as politeness) 7 .

Mentalism is reflected in the thought of Imam Musa al-Kadhim (p) through his will to his disciple Hisham ibn al-Hakam, which emphasized the mind through the Koranic approach, which emphasized the role of reason as God's argument to His slaves, in the question of faith, disbelief, misguidance, righteousness, deviation, and hadith With regard to the negatives and positives in human behavior by moving the mind or freezing it, the mind no longer has merely a force related to public faculties in his life, but turned into a basis of detailed consciousness that determines the location of wisdom in his life, which I will show in the second section, God willing.

\section{Mind Relation to Science}

One of the finest principles of Islamic education to maximize science and knowledge, scientists have mentioned the status of science and those who showed it, and expanded his statement through reason, download and Sunnah.

The Quran has referred to this in many places, including the Almighty "Read! In the Name of your Lord Who has created (all that exists).He has created man from a clot (a piece of thick coagulated blood). Read! And your Lord is the Most Generous. Who has taught (the writing) by the pen. He has taught man that which he knew not." ( Al-Alaq /1-5)., Where he opened his words to mention the blessing of finding and follow the mention of the blessing of science, if after the blessing of finding a blessing higher than science would have been worth mentioning, has been said in the face of proportionality between the verses mentioned in the chest of this Sura, some of which included the creation of human commented, and some to teach unless He knows, that the It is the Almighty to mention the first case of man means being a leech is a place of the situation, and the last case is becoming a scientist and that perfection of excellence and majesty ${ }^{8}$. Allah the Almighty says "It is Allah Who has created seven heavens and of the earth the like thereof (i.e. seven). His Command descends between them (heavens and earth), that you may know that Allah has power over all things, and that Allah surrounds all things in (His) Knowledge." (At-Taalaq/12). He made science a bug to create the upper and lower world as a way and enough for His majesty and pride, "And that those who have been given knowledge may know that it (this Quran) is the truth from your Lord, so that they may believe therein, and their hearts may submit to it with humility. And verily, Allah is the Guide of those who believe, to the Straight Path." (Al-Haj 54). And to other verses function greatness of science and honor.

As for the Sunnah of the Prophet, which indicates the virtue of science, many of them say (peace be upon him and his family and peace) (the world between the ignorant like the neighborhood between the dead, and that the student of science to ask forgiveness of all things even sea whales and phantom Seeking knowledge is obligatory for every Muslim, but God loves the prostitutes of science ${ }^{9}$ ). The imams ( $p$ ) in the virtue of science and status also came many words, including the words of Imam Ali (p) ${ }^{10}$ (ignorant is small, although the elder, and the world is great, but an event), and saying (p) (no knowledge like thinking and honor as science ${ }^{11}$ ). Science and reason are inextricably linked. It has been inferred from the virtue of science by reason. There is no doubt that the developing is better than inanimate objects, the developing is either sensitive or insensitive, the sensitive is Ashraf, then the sensible of it is sane and non-sane like man and other creatures ${ }^{12}$.The Imam alKadhim (p) relationship of reason and science and make the mind with science through saying Hashim bin rule: - that God says "And these similitudes We put 
forward for mankind; but none will understand them except those who have knowledge (of Allah and His Signs) (Al-Ankaboot / 43). Allah also says "And indeed We bestowed upon Luqman Al-Hikmah (wisdom and religious understanding) saying: "Give thanks to Allâh." And whoever gives thanks, he gives thanks for (the good of) his ownself. And whoever is unthankful, then verily, Allah is All-Rich (Free of all needs), Worthy of all praise." (Luqman / 12), said: knowledge and mind.

O Hisham, Luqman said to his son: Humility to the truth is not the most reasonable people, and that the bag of truth is going, my son: that the world is a deep sea where a great world has sunk. And its inhabitants impatient.

O Hisham: - Everything has a guide, and a guide to reason thinking, silence and reasoning guide, and everything to ride, and a wise ride humility, and enough of your ignorance to ride what you forbid.

O Hisham: - The creation of obedience to God, and escape only obedience, and obedience to science, science and learning, learning science believes, and I know only from the world of God, and the world knowledge of reason.

O Hisham: - What God sent His prophets and messengers to His slaves except to make sense of God, the best response is the best knowledge of God, and teach them by the command of God, the best mind, and their mind is the highest in the world and the Hereafter. ${ }^{13}$.

With these excerpts from the words of Imam Kadhim (p) show us how he praised the mind as a tremendous energy takes science and unique to evacuate but vague.

\section{SECTION TWO}

\section{THE USE OF VERSES OF REASON AND SCIENCE IN THE THOUGHT OF IMAM KADHUM (PBUH)}

The mind is of great importance and clear in the thought of Imam Musa al-Kadhim (PBUH). Quranic verses also, to the other and I will show the mind and its importance in the thought of Imam (PBUH) through the following things:

\section{Statement of the significance of reason in the Quran:}

He explained (p) the significance of reason by mentioning the Quranic verses that refer to him, he said at the beginning of his will to Hisham ibn al-Hakam: (O Hisham that God blessed the people of reason and understanding in his holy book "Those who listen to the Word [good advice Lâilâhaillallâh - (none has the right to be worshipped but Allâh) and Islâmic Monotheism] and follow the best thereof (i.e. worship Allâh Alone, repent to Him and avoid Tâghût) those are (the ones) whom Allâh has guided and those are men of understanding" (Az-Zumar/18).

He started by mentioning the verses that indicate the reason and reason and praising the first minds and the door, and the vilification of leaving the imposition of reason and reflection, and also some of the meanings of Quranic verses and their significance in the matter of reason and it is intended by him, said (PBUH) " OHisham, Allah the Almighty has said ( Verily, therein is indeed a reminder for him who has a heart or gives ear while he is heedful.) ( Qaaf/37)". The imam also informed that Allah has mentioned the reasoning and the mind in His saying " And indeed We bestowed upon Luqmân Al-Hikmah (wisdom and religious understanding) ( Luqmân/12).He stressed that meaning in his statement for the Almighty "Shall he then who knows that what has been revealed unto you (Muhammed)" ( Ar-Ra'd/19).

\section{The relationship of reason with the knowledge of Allah Almighty:}

Imam Kadhim (PBUH) said 'O Hisham ibn alHakam: God Almighty has completed the arguments of the people with reason and led them to the statement, and showed them his performance that He says "And your Allah (God) is One Ilâh (God - Allâh), LâilâhaillaHuwa (there is none who has the right to be worshipped but $\mathrm{He}$ ), the Most Gracious, the Most Merciful." ( Al-Baqara/163). Moreover, His saying “ And whatever you have been given is an enjoyment of the life of (this) world and its adornment, and that (Hereafter) which is with Allâh is better and will remain forever. Have you then no sense?" ( AlQassas/60). 
The Imam has also called Hisham saying " $O$ Hisham then fear those who do not make sense of his torment, as Allah has said in his Quran (And (they) said: "Are we going to abandon our âlihah (gods) for the sake of a mad poet?Nay! he (Mohammed, peace and prayers be upon him) has come with the truth (i.e. Allah's religion - Islâmic Monotheism and this Qur'ân) and he confirms the Messengers (before him who brought Allah's religion - Islâmic Monotheism) (AsSaaffaat/36-38). The imam has also said, "O Hisham and then the vilification of those who do not make sense", ( (So it was) till when Our Command came and the oven gushed forth (water like fountains from the earth). We said: "Embark therein, of each kind two (male and female), and your family - except him against whom the Word has already gone forth - and those who believe. And none believed with him, except a few.) ( Hud/40).

\section{The relationship of reason with the knowledge of Allah Almighty:}

Imam Musa Al-Kadhim (PBUH) shows the close connection between reason and knowledge of Allah Almighty, as Allah says " (They say): "Our Lord! Let not our hearts deviate (from the truth) after You have guided us, and grant us mercy from You. Truly, You are the Bestower." (Aal-i-Imraan/8). When they knew that hearts were flattened and returned to their blindness and repentance, he did not hide God who did not make sense of God, and who did not make sense of God did not hold his heart on the fixed knowledge and see the truth in his heart, and no one else but who was saying to do ratified, and pleased to openly agree Because God did not show the hidden falsehood of the mind only by a manifestation of him and speaking of $\operatorname{him}^{16}$ ).

The Imam also says (O Hisham: monument creation to obey God, and only survive obedience, obedience to science, science thought, thought, only science of the Lord and knowledge of science mind ${ }^{17}$ ). The mind is the basis of everything until knowledge of Allah Almighty.

\section{Authentic mind:}

Imam al-Kadhim (PBUH) stressed that the human mind can recognize the realities of science and devise branches and assets, and strip the faculties of the particles, but he cannot go beyond the phase that was created for him, because the mind is a balance of human can weigh things sense and experience, but it $\mathrm{He}$ cannot weigh things that are outside his stage, such as monotheism, the Hereafter, the truth of prophecy, and the truths of divine attributes.

The right mind and the presence of common sense is aware and aware of the reason for his existence between assets, thinking and reflection and using his tools in the argument and the statement and evidence, and this is meant by Imam (PBUH) authoritative reason in saying (that God has two arguments: a visible argument, and an internal argument, but the phenomenon Valsr prophets and imams (PBUH), and the Batinah minds), and in saying (PBUH) (God blessed the Almighty to complete the arguments people minds, and the prophets victory statement and evidence of the Lord's evidence).

The Imam believes the ratifications that reach certainty, such as argument, statement and evidence.

\section{Mind and its relationship to the world and the Hereafter:}

Imam al-Kadhum $(\mathrm{P})$ said in his words the link between the world and the Hereafter, and stressed in many terms the danger of adhering to the world and pride in its decoration, and leave the request of the hereafter or underestimate, this is contrary to reason, which is the inner argument to God, and contrary to what God Almighty ordered by the prophets They are the apparent argument, so he stressed the necessity of asceticism in the world and make it the means to the hereafter and this is quite prudent said ,(O Hisham: The wise asceticism in the world and wanted to hereafter, because they knew that the world is a student is required, and the Hereafter is a student is required The hereafter asked the world to meet her living, and the request of the world asked Hereafter death approaches him world and the Hereafter ${ }^{19}$ ).

Imam al-Kadhim (peace be upon him) said: (O Hisham: that the world like the living touched smooth and in the deadly poison, warns men with brains, and the boys fall into their hands, O Hisham: patience to obey God, and be patient on the sins of God, but the minimum hour, what Go from them you do not find him pleasure or sadness, and did not come from them 
you do not know, bear on that hour that you are as if you were delighted).

It is no secret that the impact of these words in clarifying the meaning and emphasis of the idea, and the validity of the behavior of the work of the mind and make him a living place.

\section{His Statement (Peace Be Upon Him) of The Qualities That Characterize the Wise:}

After Imam Kadhum (PBUH) the importance of the mind and described, praised the wise and their maqam and their qualities, which they are characterized, these qualities that they have not meet with others, because they are attributes of their actions, they are committed to the limits of God Almighty thankful to him in all their situations (In describing them) O Hisham: The wise man does not occupy the halal thanks, and does not overcome the forbidden patience, O Hisham: a little work of the reasonable acceptable multiplier, and a lot of work from the people of fancy and ignorance payoff, O Hisham: The wise is pleased without the minimum of wisdom, and did not Satisfied without wisdom with the world so I won their trade, O Hisham: that the wise left curiosity of secular life, so how sins, leaving the secular life of credit, leaving sins from imposition ${ }^{21}$ ).

The Imam has also said in praise of the wise and paradoxically reprehensible qualities: (O Hisham: that the wise does not happen who is afraid of denying him, and does not ask those who are afraid to prevent it, and is not what is not capable of it, and does not hope what violates his hope, and does not progress on what is afraid of helplessness, And the Commander of the Faithful (peace be upon him) recommend his companions say (I command you fear of God in secret and public, and justice in contentment and anger, and gain in poverty and richness, and that you reach your wombs, and forgive those who wronged you, and compassionate on your campus, and let your eyes through, and your health thought, And your saying is mentioned, and your nature is generous, it does not enter paradise with stingy, and does not enter the generous fire) O Hisham: The wise man does not lie and he liked it ${ }^{22}$ ).
These qualities that the Imam (peace be upon him) cannot have a human being without his mind is supreme.

\section{The relationship of reason with wisdom:}

Wisdom is the fruit of science, and the credibility of reason, and not only get science, so Imam al-Kadhim (p) stressed it, and urged to ask and not to waste, the whole world does not equal wisdom when its people, and does not reach its limits, says (peace be upon him) (O Hisham: Do not grant Ignorance wisdom oppressing people, and do not prevent her people then you oppress people, O Hisham as they left you wisdom, leave them the world ${ }^{23}$ ).

He says (peace be upon him): (O Hisham: sitting the people of religion honor of the world and the Hereafter, and the consultation of the mentor advises the blessings and guidance and guidance from God, if the wise adviser advised you and disagreement is in that damage $\left.{ }^{24}\right)$.

Wisdom requires taking into account the types of people and choose their cohabitation, and teach them the truth and its people, and closest to God.

Then (peace be upon him) shows the need to work with wisdom and not just take it, linking science to work there is no use of wisdom if we do not work, Imam (peace be upon him) quoted Christ (peace be upon him) saying: (O Hisham: that Christ (peace be upon him) He said to the Apostles ... Truly I say to you: People in wisdom are two men: a man who has mastered it by saying it and believing it by doing it, and a man who has perfected it by saying it and wasting it by doing badly. If they kneel, God will revive the dead hearts with the light of wisdom, as well as the dead earth with rain. ${ }^{25}$ ).

\section{Mind and ignorance:}

Imam (PBUH) shows the qualities of the mind and the qualities of ignorance, a set of qualities related to the mind and his wealth of dignified things topped by good, and the ignorance of the descriptions of evil, led by evil, so Imam (PBUH) confirms to his student Hisham ibn al-Hakam these qualities he says (O Hisham: I know the mind and recruits, ignorance and recruits were not converts ${ }^{26}$ ). 
Guidance is related to knowledge and knowledge is the way of science and science without reason, and knowledge of the mind and recruited fruit of guidance.

From the interview between the qualities of the mind and the qualities of ignorance it is clear to us that the precise and gentle tendency to entice the work of the mind, and to show qualities, and intimidation of the qualities of ignorance and abandon.

The comparison is inevitable between the two as long as the human endowed intellect mind, and the heart is aware, will choose what is the most correct case, and do for himself, and I hope for his Lord, if man knows the parameters of reason, and approach the way of knowing God, and knowing himself and others, realize the concepts of the mind and qualities and how Reasoning and health are obedience and obedience to science, science by learning, and learning by reason, as stipulated by Imam al-Kadhim (PBUH),He (peace be upon him) to those qualities, which include: humility, honesty, and endorsement of work, modesty, and closeness to God, compassion, and thanks, and others, and also pointed to the qualities of ignorance, including: arrogance, and growing, and fascination secular life, altruism and passion for the desire to Allah Almighty ........ and others.

\section{The role of reason in virtues:}

Mind is the basis of virtues and the fountain of etiquette. A person is not called virtuous until he is rational, knowing what he should influence from good, or avoiding evil, because virtuous morals are the obligations of the right mind. If one's mind is easy to overcome the problems and difficulties of life, then the mind is authorized $\mathrm{He}$ is the guide to righteousness and righteousness, and the conductor of goodness, and the compassion for mercy, and that says Imam Al-Kadhim (peace be upon him): (O Hisham: What is divided between the slaves better than the mind, the wise sleep better than watching the ignorant, and God sent a prophet wise, so that His mind is better than all the efforts of the hardworking, and the slave led the duty of the statutes of God until the mind of him).

The mind when the Imam (peace be upon him) a machine to distinguish and scrutinize the things of life, and by looking at the principles of things and their supplies and consequences, and the will of good, distracted from evil, and this mind distinguishes mankind's and evil, right and wrong, good and ugliness, science and ignorance, obedience and disobedience, mind light shines The way of virtues and beauties.

\section{CONCLUSION}

The following results can be drawn from the research:

1. The uniqueness of Imam al-Kadhim (peace be upon him) with the requirements of reason and its concept in various aspects, such as revealing its goals and addressing its deviations, and the formulation of its perfection and the elaboration of its purposes.

2. Definition of the mind and the statement of its importance, and the description of its qualities, and virtues and determine the signs of reason and authoritative.

3. Statement of the relationship of reason with science, and the fact that man is a way to know God.

4. praise the wise and mentioned their qualities and the advantages of their actions and the consequences of their behavior and proximity to God Almighty.

5. Determining the qualities of the mind and the qualities of ignorance.

6. How to build a human being and behavior, and its reflection on his actions.

7. The Imam believes in a sound mind and pure instinct if they share a single path leading to a unified purification of impurities, has linked the mind and knowledge of God and what the mind decides after meditation in the Kingdom of God Almighty and unification resulting from the need for a mastermind of this kingdom in Creation and creativity

8. The thought that expresses the mature level of vision, approach and achievement should appear with its original data to the people because this thought exists only when the people of the house (peace be upon them) as a manhole of this huge thought, which takes from the normal mind and noble instinct high wisdom that the unification of God Almighty, there is no bargaining Ahl al-Bayt (peace be upon them) in their intellectual product 

because they are the creators of this approach is clear.

\section{REFERENCES}

1. The Holy Quran

2. Sailor Al-Anwar University for the news of Imams Al-Athar, Mohammed BaqerMajlesi, publications of the Foundation fulfillment, 2nd floor, Beirut Lebanon, $d$.

3. The crown of the language and the Arabic chapter, Ismail bin Hammad al-Jawhari, Achievement: Ahmed Abdel Ghafour, Dar al-Elm for Millions, i 4, Beirut, 1407.

4. Antiques minds, son of Harrani Division, House of Cultural Affairs, Baghdad, d. T .

5. Gharr governance and the role of speech, Abdul Wahid Amadi, University of Tehran, i 1, Iran, 1360 $\mathrm{AH}$.

6. Educational Thought of the Imamate Shiites, d. Alaa al-Din Sayyid Amir al-Qazwini, Al-Faqih Library, 2nd Floor, Kuwait, 1407 - 1986.

7. Al-Kafi, Abu Ja'far Muhammad ibn Ya'qub alKulayni, Investigation: Ali Akbar Ghafari, Haidariyya Printing Press, Iran, 1388.

8. Book of the eye, Hebron bin Ahmed al-Farahidi, investigation: Mehdi Makhzoumi, Ibrahim Samarrai, Al-Alami Foundation, Beirut 1988.

9. Islamic School, Mohammed Baqir al-Sadr, Dar alZahra for printing and publishing, 3rd floor, Beirut, 1400 AH-1980 AD.

10. Language Standards, Ahmad Bin Faris, Mustafa Al-Babi Al-Halabi Library, 2nd Floor, Cairo, 1981. 